\title{
The Effect of Increasing Weight During Pregnancy on Newborn Baby Weight at Khodijah Daulay Clinic
}

\author{
Siti Khadijah Batubara \\ Lecturer of the Akademi Kebidanan Armina Center Panyabungan, Indonesia
}

\begin{tabular}{|c|c|}
\hline Article Info & ABSTRACT \\
\hline Article history: & \multirow{11}{*}{$\begin{array}{l}\text { Factors that can affect the birth weight of a baby include internal } \\
\text { environmental factors, external environmental factors, and factors related to } \\
\text { the use of health facilities related to the frequency of pregnancy check-ups } \\
\text { or antenatal care. This study aims to identify the effect of increasing body } \\
\text { weight during pregnancy on the birth weight of the baby. The research } \\
\text { design used in this research is descriptive correlation. The instrument in this } \\
\text { study was secondary data obtained from data at the Khodijah Daulay Clinic, } \\
\text { KMS for pregnant women, delivery records, and birth weight of the baby. } \\
\text { The results showed that the average weight gain of the respondents during } \\
\text { pregnancy was } 10.74 \mathrm{Kg} \text { with a standard deviation of } 1.358 \text { and the lowest } \\
\text { weight gain was } 10 \text { while the highest weight was } 16 \mathrm{Kg} \text {. From the results of } \\
\text { statistical tests with Product Moment Correlation, it was obtained that p } \\
\text { value = 0.000 had a significant effect between increasing body weight } \\
\text { during pregnancy and newborn weight. And also obtained a value ( } \mathrm{r}=0.733 \\
\text { ) this means that the influence is quite strong with a positive direction, } \\
\text { meaning that the more the mother's weight increases during pregnancy, the } \\
\text { more the baby's weight increases. }\end{array}$} \\
\hline Received December 12, 2022 & \\
\hline Ke & \\
\hline Ac & \\
\hline Corresponding Author: & \\
\hline Siti Khadijah Batubara & \\
\hline Lecturer of the Akademi & \\
\hline Kebidanan Armina Center & \\
\hline Panyabungan, Indonesia & \\
\hline Email: & \\
\hline $\begin{array}{l}\text { sitikhdijahbatubara90@gmail.c } \\
\text { om }\end{array}$ & \\
\hline
\end{tabular}

Keywords:

Gain, Weight, Baby Born

This article is licensed under a Creative Commons AttributionShareAlike 4.0 International License.

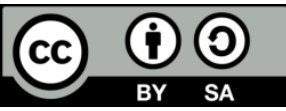

\section{INTRODUCTION}

Factors that put a woman's nutrition at risk, such as poverty, lack of education, poor environment, unusual eating habits, poor health conditions will continue to affect nutritional status and fetal growth and development. Pregnant women with poor nutritional status need special care. Race can affect the final outcome of pregnancy [3]. Increase in plasma volume ranges from $50 \%$ and $20 \%$ increase in maternal hemoglobin levels. The average weight gain of pregnant women during pregnancy is around $11.5 \mathrm{~kg}, 25 \%$ for the fetus, the rest is increased maternal blood volume, uterus and mammary gland tissue, amniotic fluid and placenta. Therefore, it is necessary to carry out Antenatal Care to follow the growth and development of the fetus, so that women and their families need to prepare for pregnancy tasks [7].

The recommended weight gain for a normal pregnancy is about 10-15 kg [5]. Weight gain during pregnancy varies for each pregnant woman, depending on several factors. The thing to remember is that pregnancy is not a time for dieting to lose weight or overeat. As stated [13]. The results of the Indonesian Ministry of Health survey in 2016 showed that $41 \%$ of pregnant women in Indonesia suffered from malnutrition, with $51 \%$ suffering from anemia. This situation makes mothers tend to give birth to babies with low birth weight (LBW) [19].

Maternal weight gain during pregnancy is directly related to the weight of the baby, and the risk of giving birth to LBW increases with the lack of weight gain during pregnancy. This shows that there is a significant relationship between the weight gain of pregnant women and the birth weight of the baby [8]. Based on the above background, the authors are interested in conducting a research entitled The Effect of Weight Gain During Pregnancy on Baby Weight at Khadijah Daulay Clinic in 2022. 


\section{METHOD}

The concept is an abstraction of a reality so that it can be communicated and form a theory that explains the relationship between two variables, namely the independent variable and the combination of the dependent variable [10]. The independent variable in this study was weight gain during pregnancy, while the dependent variable was the weight of the newborn. This study was conducted to see whether or not there was a relationship between the variables measured, namely the effect of increasing body weight during pregnancy on the weight of the newborn. From this description, it can be described the framework of the research concept as follows:

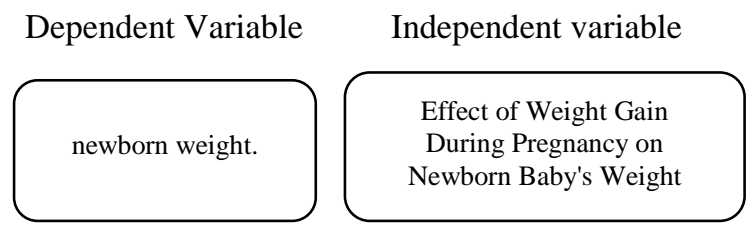

Image 1. The framework of the research concept

The sample in this study were mothers who gave birth and newborns at the Khodijah Daulay Clinic. The sample taken in this study is a total sampling of 35 people, so each member of the population who meets the requirements has the same opportunity to be sampled in this study. The sample criteria that will be used are:

Pregnant women who check their pregnancy at the Khodijah Daulay Clinic.

Mothers who gave birth at the Khodijah Daulay Clinic.

Data analysis was carried out using the help of a customized program, with the following steps:

a. Univariate Analysis:

This analysis is used to describe the independent variables and respondents in order to obtain a description and characteristics of the sample by making a frequency distribution table.

b. Bivariate Analysis:

This analysis is used to test whether there is an effect of increasing body weight during pregnancy on the baby's weight.

The hypothesis will be tested using the product moment correlation analysis technique. This correlation analysis technique is used to find the correlation coefficient or the strength of the relationship. Significant level $(\alpha=0.05)$, guidelines for accepting the hypothesis: if $\mathrm{P}$ value $<0.05$ then $\mathrm{H} 0$ is rejected, if $\mathrm{P}$ value $>0.05$ then $\mathrm{H} 0$ fails to be rejected. The data is presented in tabular form to easily see the relationship between weight gain during pregnancy and newborn weight.

\section{RESULTS AND DISCUSSION}

This chapter will describe the results of research on the effect of increasing body weight during pregnancy on baby weight at the Khodijah Daulay Clinic in 2022. The number of respondents obtained was 35 people.

\subsection{Results}

\subsubsection{Univariate Analysis}

This univariate analysis aims to describe each relationship between the variables studied. Namely looking at the relationship between the weight of the mother during pregnancy to the weight of the newborn. Categorical data are age, education and occupation, parity, pregnancy interval, ANC visits. Numerical data are searched for the mean, median and standard deviation, namely

From the results of statistical tests obtained data that the majority of respondents are aged 20-25 years as many as 13 people (37.1\%). Based on the education level, the majority of respondents have high school education as many as 15 people (42.9\%). Based on the occupation the majority of respondents are housewives as many as 18 people (51.4\%). Based on parity, the majority of skundiparous respondents were 12 people (34.3\%).

Based on the distance between pregnancies, the majority of respondents were 2 years pregnant, namely 14 people (40.0\%). Meanwhile, based on ANC visits, the majority of respondents had their contents checked 3 times during pregnancy as many as 12 people (34.3\%). From the results of statistical tests on the respondent's weight gain during pregnancy, it can be described with a mean value of 11.89, with a standard deviation of 1.937, the lowest weight gain was $10 \mathrm{Kg}$ and the highest weight gain was $15 \mathrm{Kg}$. It can be seen in the following table 1: 
Table 1. Distribution of Respondents Based on Weight Gain During Pregnancy

\begin{tabular}{ccccc}
\hline Variable & mean & SD & Min - Max & N \\
Weight Gain During Pregnancy & 11,89 & 1,937 & $10-15$ & 35 \\
\hline
\end{tabular}

From the results of statistical tests on the weight of newborns it can be described with a mean value = 3011.43 , with a standard deviation $=435.736$ and the lowest weight gain is $2000 \mathrm{~g}$ while the highest weight is 4000 g. It can be seen in table 2 below:

Table 2. Distribution of Respondents Based on Newborn Weight

\begin{tabular}{ccccc}
\hline Variable & Mean & SD & Min - Max & N \\
Newborn Baby's Weight & 3011,43 & 435,736 & $2000-4000$ & 35 \\
\hline
\end{tabular}

\subsubsection{Bivariate Analysis}

This analysis was used to examine the effect of increasing maternal weight during pregnancy on the weight of the newborn. The correlation test can be seen in the table below. Based on the statistical test of the relationship between the variables of weight gain during pregnancy and the weight of the newborn, the value of $r=0.733$, which means that there is a strong correlation between variables, with a positive direction. That is, if one variable increases, the other variable will decrease, or if the independent variable has a large value then the dependent variable becomes small. The value of $\mathrm{P}=0.000$ means that there is a significant effect. It can be seen in table 3 below:

Table 3. The Effect of Weight Gain During Pregnancy on Newborn Baby's Weight at Khodijah Daulay Klinik Clinic

\begin{tabular}{ccc}
\hline Variable & $\mathrm{R}$ & $\mathrm{Value} \mathrm{P}$ \\
Weight gain during pregnancy on the weight of the newborn & 0,733 & 0,000 \\
\hline
\end{tabular}

\subsection{Discussion}

Based on the results of the study, a discussion of the differences between the results of this study and the related literature will be described. Namely the effect of increasing maternal weight during pregnancy on the weight of the newborn.

\subsubsection{Characteristics of Respondents}

Based on the age characteristics of the respondents, it was found that the majority of respondents aged 20-25 years were 13 people $(37.1 \%)$, based on the characteristics of education the majority of respondents had high school education as many as 15 people $(42.9 \%)$, based on the characteristics of the work the majority of respondents were housewives stairs as many as 18 people $(51.4 \%)$, based on the parity characteristics of the majority of skundiparous respondents as many as 12 people $(34.3 \%)$, based on the characteristics of the distance between pregnancies the majority of respondents were 2 years gestational distance as many as 14 people $(40.0 \%)$, based on the characteristics of ANC visits, the majority of respondents had their pregnancy checked 3 times during pregnancy, as many as 12 people $(34.3 \%)$.

\subsubsection{Respondent's weight gain during pregnancy}

Based on the weight gain during pregnancy in 35 respondents, the mean value $=11.89$, with a standard deviation $=1.937$ and the lowest weight gain was $10 \mathrm{~kg}$ while the highest weight was $15 \mathrm{~kg}$. It can be concluded that the majority of respondents have an ideal weight gain. This is in line with the assumptions of [5]. The recommended weight gain for a normal pregnancy is about $10-15 \mathrm{~kg}$. Weight that is less or much more than normal will threaten the development of the baby and complicate pregnancy and childbirth.

\subsubsection{Newborn baby weight}

Based on the weight of newborns, the 35 respondents got the mean $=3011.43$ with standard deviation $=$ 435.736 and the lowest weight gain was $2000 \mathrm{~g}$, while the highest weight was $4000 \mathrm{~g}$. According [12] at birth, babies weigh about $3 \mathrm{~kg}$ and body length is $50 \mathrm{~cm}$. Nutrition of pregnant women determines the birth weight of the baby to be born, so monitoring the nutrition of pregnant women is very important. Because nutritional deficiencies during pregnancy can have a detrimental effect on both mother and child 


\subsubsection{Effect of weight gain during pregnancy on newborn body weight}

Based on the calculation of statistical tests on 35 respondents, it can be seen that the results obtained with a correlation value of 0.733 which means that there is a fairly strong influence between these variables in a positive direction. That is, if one variable increases, the other variable will decrease, or if the independent variable has a large value then the dependent variable becomes small.

The results of this study are in accordance with the assumptions of [22], maternal weight gain during pregnancy has a direct effect on the baby's weight, and the risk of giving birth to low birth weight increases with the lack of weight gain during pregnancy. This shows that there is a significant effect between the weight gain of pregnant women and the birth weight of the baby. According to the assumptions of [5], the recommended weight gain for a normal pregnancy is about $10-15 \mathrm{~kg}$. Weight that is less or much more than normal will threaten the development of the baby and complicate pregnancy and childbirth. From the results of the discussion, the researcher can conclude that the increase in maternal weight during pregnancy affects the weight of the newborn.

\section{CONCLUSION}

Based on the results of research and discussion on the effect of increasing maternal weight during pregnancy on newborn weight, it can be concluded as follows: 1). From the results of statistical tests on 35 respondents based on weight gain during pregnancy, the results can be described, namely the mean value $=11.89$, with a standard deviation $=1.937$ and the lowest weight gain is $10 \mathrm{~kg}$ while the highest weight is $15 \mathrm{Kg}$. 2). From the results of statistical tests on 35 respondents based on the weight of newborns, the results can be described, namely the mean = 3011.43 with a standard deviation $=435.736$ and the lowest weight gain is $2000 \mathrm{~g}$ while the highest weight is 4000 g. 3). From the results of statistical tests on 35 respondents obtained a $P$ value $=0.000$, it can be concluded that there is a significant effect between weight gain during pregnancy and the baby's weight. The value of $r=0.733$, it can be concluded that there is a fairly strong influence, with a positive direction, which means that if one variable increases, the other variable will decrease.

\section{ACKNOWLEDGEMENTS}

Author thanks all the teams who participated in making this research and journal article a success.

\section{REFERENCES}

[1] Alwi,Hasan, Indonesia Dictionary. Vol. 3. Ed 3. Balai pustaka, Jakarta, 2015.

[2] Arikunto, Suharsimi, Research Procedure A Practical Approach. Vol 2 Ed revision VI .PT. Rineka cipta, Jakarta, 2016.

[3] Bobak, Irene M. and friends, Maternity Nursing Textbook. Vol. 4 Ed 4, EGC. Jakarta, 2015.

[4] Hidayat,A. Aziz Alimul, Midwifery Research Methods \& Data Analysis Techniques.Vol. 1 Ed 1, Salemba Medika, Jakarta , 2017.

[5] Macdougall, Jane, Pregnancy Week By Week, Vol. 1 Ed 1, PT Gelora Aksara Pratama, Jakarta, 2013.

[6] Machfoedz, Ircham, Research methodology, Vol. 2 Ed 2, Fitramaya. Yogyakarta, 2019.

[7] Tomy, "Comparative Study of Hemoglobin Levels and Maternal Uterine Fundal Height on Normal and Low Birth Weight Outcomes" 2018, .http://repository.usu.ac.id/bitstream/123456789/6457/1/08E00813.pdf. Accessed on 20 December 2021 at $15.30 \mathrm{Wib}$.

[8] Murkoff, Heidi. and friends, What Pregnancy Are You Facing Month By Month. Vol. 3 Ed 3, Arcan., Jakarta, 2016.

[9] Notoatmojdo, Health Research Methodology. Vol. 1 Ed 1, PT. Rineka cipta. Jakarta, 2013.

[10] Nursalam, Concept and Application of Nursing Research Methodology., Vol. 2 Ed 2, Salemba Medika, Jakarta, 2018.

[11] Pudjiadi, Clinical nutrition in children, Vol. 1 Ed 2, Balai Penerbit FK UI, Jakarta, 2013.

[12] Solihin, Pudjiadi, Clinical Nutrition in Children., Vol 1 Ed 1, Balai Penerbit FKUI, Jakarta, 2013.

[13] Suririnah, Pregnancy and Childbirth Smart Book, Vol. 1 Ed 1, PT. Gramedia Pustaka Utama, Jakarta, 2018.

[14] Suyanto.\& Salamah, Ummi, Midwifery Research Methodology \& Application, Vol 1 Ed 1, Mitra Cendikia Press, Yogjakarta, 2013.

[15] Setianingrum, S.I.W., The Relationship Between Weight Gain, Upper Arm Circumference and Hemoglobin Levels of Pregnant Women in the Third Trimester and Birth Weight of Babies at Ampel I Public Health Center Boyolali in 2005. Universitas Negeri Semarang, 2005.

[16] Simanjuntak, N.A., The Relationship between Anemia in Pregnant Women and the Incidence of Low Birth Weight (LBW) at the General Hospital Management Agency (BPRSU) Rantau Prapat, Labuhan Batu Regency, Universitas Sumatra Utara Medan. 2009.

[17] Tela FG, Bezabih AM, Adhanu AK (2019) Effect of pregnancy weight gain on infant birth weight among mothers attending antenatal care from private clinics in Mekelle City, Northern Ethiopia: A facility based follow-up study. PLoS ONE 14(3): e0212424. https://doi.org/10.1371/journal.pone.0212424.

[18] Barker DJ, Gluckman PD, Godfrey KM, Harding JE, Owens JA, Robinson JS. Fetal nutrition and cardiovascular disease in adult life. Lancet. 1993;341:938-941. https://doi.org/10.1016/0140-6736(93)91224-a.

[19] Eriksson J, Forsen T, Tuomilehto J, Osmond C, Barker D. Size at birth, childhood growth and obesity in adult life. Int J Obes Relat Metab Disord. 2001;25:735-740. https://doi.org/10.1038/sj.ijo.0801602.

[20] Eriksson M, Wedel H, Wallander MA, et al. The impact of birth weight on prostate cancer incidence and mortality in a population-based study of men born in 1913 and followed up from 50 to 85 years of age. Prostate. 2007;67:1247-1254. https://doi.org/10.1002/pros.20428.

[21] Jenifer Ng, Magee L A, Yarker E K. Maternal Overweight and Excess Gestational Weight Gain: Identification of Maternal and Perinatal Implications and Primary Maternity Caare Providers' Opportunities for Interventions to Improve Health Outcomes. Departements of Medicine, Obstetric and Gynecology and Population and Public Health, University of British Columbia, Vancouver, BC. 2009.

[22] Islam A, Khan NA, Ehsan A. Complications of Raised BMI in Pregnancy. Professore Med J 2010, 17(3);498-504. https://dx.doi.org/10.18203/2320-1770.ijrcog20163863.

[23] Viswanathan M, et al. Outcomes of Maternal Weight Gain, Evidence Report/Technology Assessment No 168. AHRQ Publication No. 08. Ed 009. Rockville, MD; Agency for Healthcare Research and Quality. 2008. 
[24] Oken E, Taveras EM, Kleinman KP, Rich-Edwards JW, Gillman MW. Gestational weight gain and child adiposity at age 3 years. Am J Obstet Gynecol 2007; 196:322.e321-8. https://doi.org/10.1016/j.ajog.2006.11.027.

[25] Claesson IM. Weight gain restriction for obese pregnant women: a case-control intervention study. BJOG 2008; 115: 44-50. https://doi.org/10.1111/j.1471-0528.2007.01531.x. 